\title{
Sharing Human Resource Management Responsibility to Line management for Organizational Performance: Results from Nepal
}

\author{
Dhruba Kumar Gautam (Ph.D.) \\ Associate Professor, Faculty of management, Tribhuvan University \\ Kathmandu, Nepal \\ Email: dhrubakumargautam@yahoo.com
}

\begin{abstract}
The purpose of this paper is to examine the situation of assignment of human resource (HR) management roles and responsibility to the line management in business organizations of Nepal and to analyze the contribution of high devolved and less devolved organizations on overall organizational performance. This survey based on exploratory research assumes individual organization as a unit of analysis. Data through structured questionnaire received from 105 organizations are inserted into SPSS 11.5 and statistical tool like t-test, f-test, were used for the analysis. The perceptual measurement of financial performance and market share is also verified with the support of published data. The result of this study highlights the assignment of HR management responsibility to the line management in listed companies of Nepal and shows the differences in between more assigned and less assigned organizations. It reaches into the conclusion that high devolved organizations contribute positively in their performance in terms of quality of product, level of labor productivity, financial performance, and employee satisfaction, rate of innovation, employee commitment, and market share than less devolved organizations.
\end{abstract}

KEYWORDS: Human Resource management, Assignment of Human Resource Roles and Responsibility, Line management Organizational Performance, Nepal

\section{BACKGROUND}

The assignment of HR management roles and responsibilities to line management has been increasing since 1990s (Cunningham and Hyman, 1995; Hutchinson, 1995; Hutchinson and Wood, 1995; IRS, 1994; Storey, 1992) and is gaining its recognition in the literature (Torrington, 1989; Schuler, 1990, 1991; Brewster and Soderstrom, 1994). It is defined as the degree of devolving employee management roles and responsibilities from personnel department to line management (Brewster and Soderstrom, 1994). The most common pattern of assignment is the sharing on decision-making issues of HR management between HR specialist and line management (Legge, 1995; Brewster et al. 1997, Larsen and Brewster, 2003), which is becoming a common trend among the large organizations (Cunningham et al., 1996; Lowe, 1992).

Earlier results of studies on assignment of $\mathrm{HR}$ management roles and responsibilities to line management conducted in developed countries of Western world proved how assignment leads to the better organizational performance (Brewster and Larsen, 2000; Ulrich, 1998; Jackson and Schuler, 2000; Budhwar and 
Sparrow, 1997; Torrington, 1989). These authors argue that the assignment of HR management responsibility to line management reduces the operating costs, speeds up in decision-making process, integrates HR into organizational targets, motivates employees for efficiency, and facilitates to control people and other resources effectively. However, there is a dearth of such studies of assignment of HR management responsibility to line management in the context of developing countries of South Asia like Nepal. Few researchers of Nepal have initiated research in HR related issues like: Adhikari and Mueller (2004), Adhikari (1999; 2001), Adhikari and Gautam (2007; 2008; 2009 forth coming), Gautam and Davis (2007). In Nepal Adhikari (2001) observed that: "The Nepalese context does not appear favorable to many aspects of American or European HR management concepts. Prescriptions for the devolvement of human resource management responsibility to line managers are one example. This is difficult because of the limited knowledge and skills of many managers. Furthermore, Nepalese decision-makers often prefer to hold the power rather than delegate and devolve it." With these caveats in mind, this article aims to identify the degree of devolvement of HR responsibilities to line managers and its impact on organizational performance in Nepalese organizations.

\section{The Debate of Assignment of HR management responsibility to Line Management}

The classical relationship between HR specialists and line mangers has come under practical and scientific attack (Brewster et al., 1997). Given the concepts like lean management or hierarchical organizations (Hedlund, 1986) the efficiency of large centralized units where HR "know-how" is concentrated has been questioned. Brewster et al. (1997) further state that: "Rather than relying solely on central specialists, the argument is made that HR responsibilities should be moved towards line managers; and line mangers should undertake, and monitor, HR activates such as recruitment, performance assessment, and reward'.

In fact, there is a trend emerging in European nations that to give line managers to manage staff of their departments and reduce the size of HR department and its control (Brewster and Larsen, 2003). The reason of evolving the assignment of HR management responsibility to line management is that personnel practitioners are seen to be out of touch with commercial realities, and unable to comprehend the nature of business, its customers, or its corporate goals (Budhwar and Sparrow, 1997; Budhwar, 2000). The decisions formulated by personnel managers have little relevance for competitive prospects and hard to put into effect (Whittaker and Marchington, 2003). Line management has to involve with HR department to bear primary responsibility of people management in order to make closer link between strategy development and HR development, which will lead to a systematic and consistent use of human resource policies to achieve their operating goals (Cunningham and Hyman, 1999).

The HR management function is seen as playing the role of coordinator and catalyst for the activities of line managers - a management team player working jointly with the top management solving people related business issues (Schuler, 1990). The study of Guest (1989) found that line mangers accepted and used HR management practices as a part of their everyday work. Therefore, it is wise for line managers to 
take even greater responsibility for people management activities. The ultimate responsibility of HR by line management ownership may increase their commitment to integrate HR with business objectives (Whittaker and Marchington, 2003).

However, the assignment of HR responsibility to the line management is not seen unproblematic (Larsen and Brewster, 2003). The line managers need to understand HR management practices that build up organizational capabilities, which become a critical source of competitive advantage (Burke and Cooper, 2005). They have more pressing priorities than managing and developing the people working for them. Therefore, they take people management issues less seriously than production goals and they did not feel any institutional pressure to consider HR issues seriously (Gratton et al., 1999). They are not able to devote sufficient time (Cunningham and Hyman, 1999) and do not possess the skills and competencies necessary to perform the HR issues. Line managers do not possess the skills and competencies necessary to perform the HR aspect of their jobs effectively without support from personnel practitioners (IRS 1994; 1995; 1996; 2000). They are often ignorant about recent development in the areas of HR management and are poor at making comprehensive longer-term views of HR policies (Larsen and Brewster, 2003). Similarly, they may not have time to deal with it properly and the relationship between HR specialists and line managers is not a simple one due to their different level of hierarchy that makes difficult to describe exactly senior or junior line or HR managers (Larsen, 2003; Larsen and Brewster, 2003). It is said that line managers are unlikely to acquire the primarily responsibility of human resource management without continuing support from HR specialists (Cunningham and Hyman, 1995). HR function could be disbanded if only line managers are given to accept this responsibility (Cooper, 2001). As Ulrich (1998) noted, to be truly tied to business outcomes, HR needs to join forces with operating managers to systematically assess the impact and importance of initiatives.

The review of literature provides glimpse of development in the specific areas of devolvement of HR responsibility to the line managers (Table 1 ). 
Table 1: List of research in the area of assignment of HR responsibility with authors and main ideas

\begin{tabular}{|c|c|}
\hline Authors & Main Premise \\
\hline $\begin{array}{l}\text { Barney and Wright } \\
(1998)\end{array}$ & $\begin{array}{l}\text { HR department should help line managers resolve business } \\
\text { issues and align to achieve goals. }\end{array}$ \\
\hline $\begin{array}{l}\text { Brewster and } \\
\text { Soderstrom (1994); } \\
\text { Brewster and Larsen } \\
(1992 ; 2000)\end{array}$ & $\begin{array}{l}\text { Recognized the importance of devolvement of HR } \\
\text { management practices to the line management, they found } \\
\text { the increasing trend of devolution of HR responsibility to line } \\
\text { management. }\end{array}$ \\
\hline $\begin{array}{l}\text { Budhwar and } \\
\text { Sparrow (1997) }\end{array}$ & $\begin{array}{l}\text { Low level of devolvement of HR management practices } \\
\text { practiced in Indian organization }\end{array}$ \\
\hline Budhwar (2000) & $\begin{array}{l}\text { Low level of devolvement of HR management responsibility } \\
\text { to line management in UK. }\end{array}$ \\
\hline Cully et al. (1999) & $\begin{array}{l}\text { Line managers are more likely to pay a part in HR decisions } \\
\text { than they had previously. }\end{array}$ \\
\hline $\begin{array}{l}\text { Cunningham and } \\
\text { Debrah (1995); } \\
\text { Cunningham and } \\
\text { Hyman (1995; } \\
\text { 1999); Cunningham } \\
\text { et al. (1996) }\end{array}$ & $\begin{array}{l}\text { Line managers take over some of the function of HR } \\
\text { managers because HR managers lacked the skills necessary } \\
\text { to perform their duties competently. Line management has } \\
\text { been viewed as increasingly taking responsibility for HR } \\
\text { management initiatives and practices. }\end{array}$ \\
\hline $\begin{array}{l}\text { Earnshaw et al. } \\
(2000)\end{array}$ & $\begin{array}{l}\text { Line managers need continuous and systematic support and } \\
\text { training from HR specialist. }\end{array}$ \\
\hline $\begin{array}{l}\text { Gennard and Kelly } \\
\text { (1997) }\end{array}$ & $\begin{array}{l}\text { Line managers are unlikely to acquire sufficient skills in the } \\
\text { HR area without HR support. }\end{array}$ \\
\hline Gratton et al. (1999) & $\begin{array}{l}\text { Line managers do not feel any institutional pressure to } \\
\text { consider HR management issues seriously. }\end{array}$ \\
\hline $\begin{array}{l}\text { Guest and King } \\
\text { (2001) }\end{array}$ & $\begin{array}{l}\text { Line management plays prominent role in HR management } \\
\text { due to HR work devolved to them. }\end{array}$ \\
\hline Guest (1989) & $\begin{array}{l}\text { HR management practices are accepted and used by line } \\
\text { managers as a part of their everyday work. }\end{array}$ \\
\hline $\begin{array}{l}\text { Hall and Torrington } \\
\text { (1998) }\end{array}$ & $\begin{array}{l}\text { Line managers make decisions in conjunction with } \mathrm{HR} \\
\text { specialist }\end{array}$ \\
\hline Huang (2000) & $\begin{array}{l}\text { Organizations that devolve HR activities to line managers } \\
\text { outperform than less devolved. }\end{array}$ \\
\hline $\begin{array}{l}\text { Hutchinson and } \\
\text { Wood (1995) }\end{array}$ & $\begin{array}{l}\text { There is greater line management involvement in } \mathrm{HR} \\
\text { management issues compared to five years before. }\end{array}$ \\
\hline $\begin{array}{l}\text { Jackson and Schuler } \\
(2000)\end{array}$ & $\begin{array}{l}\text { Line management adopts a partnership approach between } \\
\text { HR and line to manage HR issues. }\end{array}$ \\
\hline $\begin{array}{l}\text { Kirkpatrick et al. } \\
\text { (1992) }\end{array}$ & $\begin{array}{l}\text { Decentralization of responsibility to line management has } \\
\text { been viewed as a key of HR management. }\end{array}$ \\
\hline Legge (1989) & $\begin{array}{l}\text { One component of HR management is the involvement of } \\
\text { line managers. }\end{array}$ \\
\hline
\end{tabular}

(Continued...) 
Table 1: List of research in the area of assignment of HR responsibility with authors and main ideas

\begin{tabular}{|l|l|}
\hline Authors & \multicolumn{1}{|c|}{ Main Premise } \\
\hline Lowe (1992) & $\begin{array}{l}\text { The role of line management should expand so that it } \\
\text { incorporates people responsibility. }\end{array}$ \\
\hline Marchington (1999) & $\begin{array}{l}\text { Positive outcome depend on line managers being skilled in } \\
\text { HR management as they are the interpreters. }\end{array}$ \\
\hline $\begin{array}{l}\text { McGovern et al. } \\
\text { (1997) }\end{array}$ & $\begin{array}{l}\text { Develop educational and technical base of line managers for } \\
\text { effective devolution of HR management. }\end{array}$ \\
\hline Millward et al. (1992) & $\begin{array}{l}\text { Line managers are spending more of their time on personnel } \\
\text { and related activities. }\end{array}$ \\
\hline Othman (1996) & $\begin{array}{l}\text { HR management department should facilitate the devolution } \\
\text { of HR management responsibility to line managers. }\end{array}$ \\
\hline $\begin{array}{l}\text { Pool and Jenkins } \\
\text { (1997) }\end{array}$ & $\begin{array}{l}\text { The shift of HR management responsibility to the line } \\
\text { management seems to be dominance. }\end{array}$ \\
\hline Pool (1976) & $\begin{array}{l}\text { Importance of line management in the management of } \\
\text { people has been recognized. }\end{array}$ \\
\hline $\begin{array}{l}\text { Renwick (2000; } \\
\text { 2003) }\end{array}$ & $\begin{array}{l}\text { Significant organizational benefits exist from involving the } \\
\text { line management in HR work. }\end{array}$ \\
\hline $\begin{array}{l}\text { Schuler and Walker } \\
\text { (1990) }\end{array}$ & $\begin{array}{l}\text { Jointly share by HR and line managers to solve people } \\
\text { related business issues. }\end{array}$ \\
\hline $\begin{array}{l}\text { Schuler (1990; } \\
1992) ; \\
\text { Storey and Sisson } \\
\text { (1994) }\end{array}$ & $\begin{array}{l}\text { HR management function is seen as playing role of } \\
\text { coordinator and catalyst for the activities of line managers } \\
\text { solving people related business issues. }\end{array}$ \\
\hline Storey (1992; 2001) & $\begin{array}{l}\text { There is an increased role of line managers in the } \\
\text { management of HRs. }\end{array}$ \\
\hline Torrington (1989) & $\begin{array}{l}\text { Line management should give primary responsibility for HR } \\
\text { management rather than personnel specialist. }\end{array}$ \\
\hline $\begin{array}{l}\text { Ulrich (1997;1998; } \\
\text { 2001) }\end{array}$ & $\begin{array}{l}\text { To be truly tied to business outcomes, HR needs to join } \\
\text { forces with line managers. }\end{array}$ \\
\hline $\begin{array}{l}\text { Whittaker and } \\
\text { Marchington (2003) }\end{array}$ & $\begin{array}{l}\text { Line managers are satisfied with the HR responsibility that } \\
\text { has devolved to them. }\end{array}$ \\
\hline & \\
\hline
\end{tabular}

The review of literature clearly provides cases of the rising interest on assignment of $\mathrm{HR}$ responsibility to the line managers for achieving organizational benefits, business results and to solve people related business issues. Based on the review of research (Brewster and Larsen, 1992; Budhwar and Sparrow, 1997), some of the outcomes of assignment of HR responsibility to line management are: (a) It can result in better motivation of employees and more effective control, as line managers have constant contact with employees; (b) local managers are able to respond more quickly to local problems and conditions; (c) certain issues are too complex which can be jointly solved; (d) it can help reduce costs; (e) it can help prepare future managers. 


\section{Practices of Assignment}

The practices of assignment of HR roles and responsibilities to line management in Western countries are varying among the countries and advocates divergence of practices. A study of Budhwar and Sparrow (1997) in India indicates the higher level of sole responsibility of HR management department for decision over pay and reward, industrial relations, and workforce expansion and reduction. Similarly, the practice in UK indicates higher sole responsibility of line managers to health and safety, and training and development (Budhwar, 2000, Atterbury et al. 2004). Hope-Hailey et al. (1997) concluded based on eight British-based organizations that all of them were shifting responsibility for people management towards line management. HR department alone has more responsibility in Ireland than England (Atterbury et al 2004).

In Austria, there is an increase in the importance of line management on training, which is even above the EU (European Union) average. In Switzerland, the importance of line management is decreasing whereas the working together of HR with line management seems to be enforced much higher than the EU standard (Erten et al., 2004). The primary responsibility for major policy decisions on key aspects of HR management like recruitment and selection is slightly increasing in the responsibility of line management alone and line management together with HR department. In both the countries more than eighty percent organization's line management and HR department jointly bear the responsibility for recruitment and selection (Erten, et al. 2004).

Countries like Denmark and Norway are ranked very high to allocate HR responsibilities among line managers. In Norway, the primary responsibility for training and development lies with line management in consultation with HR department is much higher than the initiation of HR department, which indicates the main domination of line management (Rogaczewska et al., 2004). A survey shows that the HR responsibility of line managers in Bulgaria and, to some extent, in the Czech Republic was greater than in EU countries on an average (Koubek and Vatchkova, 2004).

Sweden and Finland have similar trend to bear primary responsibility for major decisions on key aspects of HR management. In these countries, almost half of the organization's responsibilities lie with line management in consultation with the HR department. The responsibility by HR department with line management is twenty percent and fourteen percent respectively in both the countries (Lindeberg et al. 2004). Nevertheless, Spain has the greatest variation: it has the most line management involvement on pay issues, the least on health and safety and a wide range on other issues (Brewster et al., 1997). The study in France reported that ninety percent organizations share the responsibility for recruitment jointly by line management and HR Department and Belgium trying to follows the similar trend (Buyens et al. 2004).

The primary responsibility lies with line management alone for recruitment and selection in Italy, Greece and Cyprus is also quite divergent like zero percent, eleven percent and twenty-four percent respectively. Though they shared primarily 
responsibility for training and development between $\mathrm{HR}$ specialist and line management, the responsibility lies with the HR department alone seems to be above the EU average in Italian and Cypriot organizations, while those of Greek organizations are very close to the EU average (Papalexandris and Stavrou-Costea, E., 2004).

The above discussion shows the evidence that responsibility for HR is being increasingly allocated to line managers and international survey (Brewster and Soderstrom 1994; Brewster and Larsen 1992; Brewster et al., 1997 Brewster and Larsen, 2000) confirms this more anecdotal data. However, there are no changes in the responsibility of line management in Switzerland in the last three years (Erten et al. 2004). Similarly, on average more than sixty-five percent organizations of Denmark and fifty-five percent organizations of Norway reported that there are no changes in line management responsibility on key aspects of HR management (Rogaczewska et al. 2004). In spite of these, Bulgarian and Czech organizations report a little increase in line management's responsibility for pay and benefits and for workforce expansion and reduction (Koubek and Vatchkova, 2004).

Regarding Nepal, the CRANET (2005) study revealed that: a) in thirty-eight percent organizations the primary responsibility of recruitment and selection was on line management; b) in fifty-five percent organizations line managers were found to be involved in making pay and benefits decisions; c) in case of responsibility for training and development in thirty-six percent organizations line managers are involved and d) in forty-one percent organizations line managers are involved in industrial relations issues; e) in forty-three percent organizations line managers are involved in workforce expansion/reduction. Following to this situation of sole line managers' involvement in different HR initiatives, in large number of organizations line managers are working in partnership with HR department in all these four HR initiatives. This clearly shows that in Nepalese organizations involvement of line managers is in practice while dealing with HR issues. Based on the above review of situation of line management involvement in HR practices in different countries the following main research hypothesis emerged: There is an increasing trend of assignment of HR management responsibility to line management and sharing of some of the HR responsibilities in between line management and HR department in Nepal.

\section{Assignment of HR management responsibility and HR performance}

In recent years, the line management has been seen to play a more prominent role in HR management due to more HR work being "devolved" to them (Brewster and Larsen, 2000; Currie and Procter, 2001; Guest and King, 2001; Storey, 1992; 2001; Ulrich 1997; 1998; 2001). The rationale of line management involvement in HR management has five main elements: to reduce costs; to provide a more comprehensive approach to HR management; to place responsibility for HR management with managers most responsible for it ; to speed up decision making; and to outsourcing the HR function (Brewster and Larson, 2000). Similarly, line managers are expected to do more of their own HR management and can benefit from cross training in HR processes (Mohrman and Lawler, 1999). They should lead the way in fully integrating HR into the company's real work (Ulrich, 1998); and can 
adopt a "partnership" approach between HR, line management and employees to manage HR issues, an HR triad (Jackson and Schuler, 2000).

The practice of assignment is becoming important in the increasing competitive business environment, which has led to large scale restructuring in organizations. As a result, line managers have been given primary responsibility for HR management (Budhwar, 2000). Assignment of HR management to line managers improves commitment of HR specialist towards organizations, motivates them and helps in maintaining good industrial relations (Torrington, 1989; Hope-Hailey et al. 1997). The major outcomes of assignment include more problems being solved at a lower level, better change management, more responsible line managers, improved efficiency of employees and more freedom for specialists to move away from routine activities (Budhwar, 2000). Such practice of assignment of HR management to line management certainly leads towards overall organizational performance like quality of product or service, labour productivity, financial performance, employee satisfaction, rate of innovation, employee commitment, and market share. From this reasons, we can reach into the fourth hypothesis as: Firms that have high assignment and low assignment in HR management practices to line management are different in the major financial performance variables, such as quality of product or services, level of labor productivity, financial performance, employee satisfaction, rate of innovation, employee commitment, and market share.

\section{METHODOLOGY}

A survey research design is applied to undertake this study in 121 listed companies of Nepal. The structured questionnaire survey was undertaken assuming an individual organization as a unit of analysis. At the time of survey during 20062007, there were 121 listed business organizations operating in Nepal according to Nepal Stock Exchange (NEPSE, 2007). Though, questionnaire is sent to the total population; only 105 valid questionnaires were received. Thus, the overall response received was eighty-seven percents, which is fairly larger response.

To measure the assignment of HR management roles and responsibility to the line management, respondents were asked two major questions based on Brewster and Larsen (1992), Budhwar and Sparrow (1997), Budhwar (2000), and Brewster et al. (1997): a) With whom does the primarily responsibility lie for major policy decisions in the following seven HR management practices: recruitment and selection, pay and benefits, training and development, labor relation, health and safety, performance appraisal, and workforce expansion or reduction. All these seven questions have four options for the answers: line managers alone, HR department alone, line management in consultation with HR department, HR department in consultation with line management, which are coded as 1, 2, 3, and 4 respectively. b) Has the responsibility of line management changed over the last three years for these seven HR management practices? The measurement of responsibility changed over three years is increased, same, and decreased, which are coded as 1 , 2 , and 3 respectively.

For the first question, every respondent could give total mark of at least seven and maximum twenty-eight, on these seven HR practices. The organizations which have 
the practices of partnership (consultation in between line management and HR department) and increased change of line management responsibility over three years or same in all these HR issues are recognized as high assigned organization. According to this cutoff line, those organizations, which have at least total twenty one score on these issues and have either increased or remained same of the line management responsibility in all these seven issues over the three years are considered high assigned organizations and remaining were considered as less assigned organizations.

The variables studied to measure the impact of assignment on organizational performance are: quality of product or service; level of labor productivity; financial performance; employee satisfaction; rate of innovation; employee commitment; and market share. Collected data were inserted into SPSS version 11.5, and descriptive statistics, t-test, and f-test were used to analyze the data. The Cronbach alpha of all fourteen items of measurement of assignment is 0.7133 and seven items of performance measurement is 0.8277 , in 105 numbers of cases.

The details of responding organizations and respondents are presented in Table (2).

Table 2: Details of respondents and responding organizations

\begin{tabular}{|l|r|r|r|r|r|r|}
\hline Main Sector of Business & Population & \multicolumn{5}{|c|}{ Responders } \\
\cline { 3 - 6 } & & RO & HR & LR & CEO & Others \\
\hline Commercial Banks & 15 & $15(100)$ & $12(80)$ & $2(13)$ & - & $1(7)$ \\
\hline Manufacturing and Processing * & 21 & $12(57)$ & $4(33)$ & $4(33)$ & $3(25)$ & $1(9)$ \\
\hline Insurance Companies & 15 & $15(100)$ & $10(67)$ & $2(13)$ & - & $3(20)$ \\
\hline Finance Companies & 49 & $44(90)$ & $15(34)$ & $13(30)$ & $8(18)$ & $8(18)$ \\
\hline Development Banks & 8 & $8(100)$ & $1(13)$ & $4(50)$ & $3(37)$ & - \\
\hline Others ** & 13 & $11(85$ & $3(27)$ & $4(37)$ & $2(18)$ & $2(18)$ \\
\hline Total & 121 & $105(87)$ & $45(43)$ & $29(28)$ & $16(15)$ & $15(14)$ \\
\hline
\end{tabular}

Note: RO = Responding organizations; HR = Human Resource Managers; LR = Line Managers; CEO = Chief Executive Officers; The parenthesis of the table indicates respective percent of respective numbers; * All the Hotels listed $(\mathrm{N}=4)$, four trading companies (out of eight, four were de-listed) and five others (out of six, one airline is de-listed) were considered as population of others for the study. The de-listed trading companies are: Nepal United Co. Ltd., Plastic Trading Co. Ltd., Nepal Byapar Bikash Co. (Koshi) Ltd., and Nepal Byapar Bikash Co. Ltd. Similarly, the de-listed airline company is Necon Air Ltd.; ** In Jan. 31 ${ }^{\text {st }}, 2007$ Nepal Stock Exchange decided to de-list of eight Manufacturing and Processing companies because of not qualifying as per Listing Bye Laws 2053. These are Nepal Battery Co. Ltd.; The Juddha Match Factory ; Nepal Plywood and Bobin Co. Ltd.; Himal Cement Co. Ltd.; Sayapatri Color Lab; Nepal Med Ltd.; Ace Laboratories (Nepal) Ltd.; and Bansbari Leatherage and Tannery. Therefore, only 21 companies were remained as manufacturing and processing companies.

The 82 percent of respondents of survey organizations have had University Degrees in different fields of study which cannot be generalized because of participation by high level of employees. Out of all the respondents, 55 percent have had University Degrees in Business Administration. Supporting the view of Adhikari (2004), it shows that business course has been expanding in Nepal and hiring students in workforce from business administration is increasing. The mean age of organizational establishment is 13.6 , in which the maximum age of establishment is 47 years. Similarly, the maximum age of services of the respondents in the same organization is 32 years and the mean service is 7.57 years. 


\section{RESULTS AND DISCUSSION}

Assignment of HR responsibility to Line management in Nepal

The current situation of Nepalese organizations (Table 3 ) shows that there is a higher involvement of line management for decisions over most HR management practices like: pay and benefits, recruitment and selection, training and development, and labor relations. In contrast, the sole involvement of HR management department is comparatively lower to deal with major HR issues. The involvement of $\mathrm{HR}$ management department is noticed in lesser number of organizations. In spite of the fact that line management is in domination position, the partnership in between line management and HR is a common practice in Nepalese business sector while making HR decisions. 


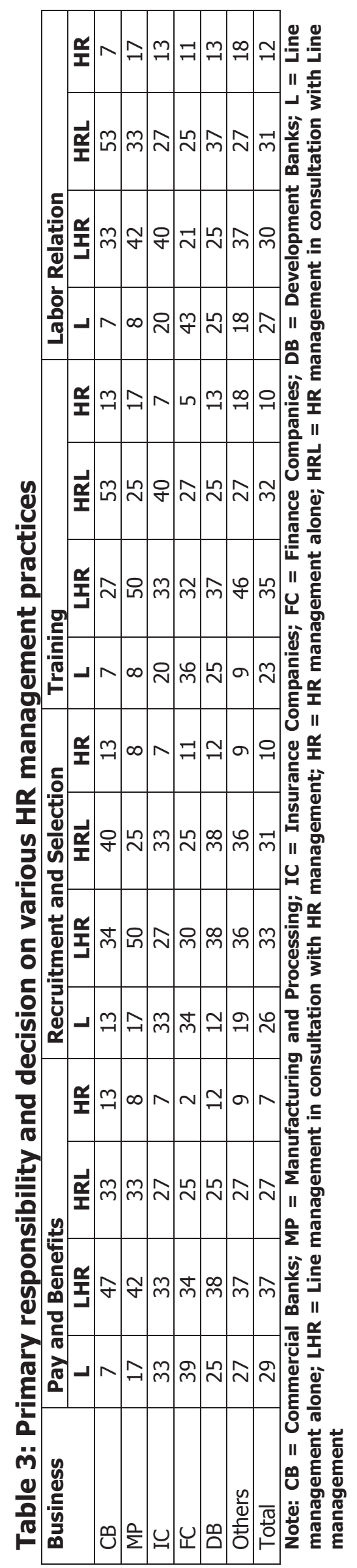


From Table (4) it appears that line managers are widely involved compared to HR managers taking responsibility and making decisions on various HR practices. Similarly, line and HR partnership is dominating than HR and line partnership. There might be different reasons for that. For example, in a study related to HR of all financial institutions putting them in a single basket, it was revealed that 50 percent organizations have no existence of separate HR department (Adhikari and Gautam, 2008). For example, first, in a study it was revealed that in $50 \%$ of banks and finance organizations there is no existence of a separate HR department (Adhikari and Gautam, 2008). Second, CEOs (Chief Executive Officer/s) and line managers may be reluctant to give up HR related power to HR professional as described by Adhikari and Mueller, (2002) that Nepalese decision-makers often prefer to hold the power rather than delegate and devolve it. Third, professional HR departments are not capable enough to hold HR related responsibility and decisions. Fourth, In case of Nepalese organizations, CEOs are personally interested in HR related decisions such as, recruitment and selection, performance evaluation, work expansion / reduction, and pay and benefits, and thus largely attempt to gain influencing power in these issues.

Table 4: Primary responsibility and decision on various practices of $H R$ management

\begin{tabular}{|l|l|l|l|l|l|l|l|l|l|l|l|l|}
\hline $\begin{array}{l}\text { Main sector of } \\
\text { business }\end{array}$ & \multicolumn{4}{l|}{$\begin{array}{l}\text { Health and } \\
\text { Safety }\end{array}$} & \multicolumn{4}{l|}{$\begin{array}{l}\text { Performance } \\
\text { Appraisal }\end{array}$} & \multicolumn{4}{l|}{$\begin{array}{l}\text { Work Force Expansion / } \\
\text { Reduction }\end{array}$} \\
\cline { 2 - 16 } & L & LHR & HRL & HR & L & LHR & HRL & HR & L & LHR & HRL & HR \\
\hline CB & 7 & 60 & 26 & 7 & 7 & 33 & 40 & 20 & 20 & 46 & 27 & 7 \\
\hline MP & 8 & 42 & 42 & 8 & 17 & 25 & 42 & 16 & 25 & 42 & 25 & 8 \\
\hline IC & 20 & 40 & 27 & 13 & 20 & 40 & 33 & 7 & 27 & 40 & 27 & 6 \\
\hline FC & 43 & 32 & 16 & 9 & 30 & 32 & 25 & 13 & 43 & 32 & 20 & 5 \\
\hline DB & 13 & 37 & 25 & 25 & 25 & 37 & 25 & 13 & 25 & 38 & 25 & 12 \\
\hline Others & 27 & 37 & 27 & 9 & 27 & 37 & 27 & 9 & 36 & 18 & 37 & 9 \\
\hline Total & 27 & 39 & 24 & 10 & 23 & 33 & 31 & 13 & 33 & 35 & 25 & 7 \\
\hline
\end{tabular}

Note: CB = Commercial Banks; MP = Manufacturing and Processing; IC = Insurance Companies; FC = Finance Companies; DB = Development Banks; $L=$ Line management alone; LHR = Line management in consultation with HR management; HR = HR management alone; HRL = HR management in consultation with Line management

Specifically, in more than one-fourth organizations, line managers play the sole role and bears full responsibility while making decisions on health and safety. Nearly in two-third organizations HR management responsibility has been jointly shared by line management and HR management department. Except in development banks, rest of other business organizations have minor role of HR management department. Line managers in these organizations are working in consultation with HR management department to deal with HR management issues.

\section{Changes on Sharing Responsibility}

The role of line management involvement in major HR practices is increasing in listed companies of Nepal. Except in Labor relations and Health and safety, there is a clear trend of increasing role of line management over the last three years. There are forty-five to fifty-one percent of Nepalese organizations with increasing HR responsibility to the line management over HR management issues. 
Table (5) depicts that majority of the organizations have indicated that there is either an "increased" or "same" trend of line management involvement while making decisions on different HR activities. This also reveals the fact about involvement of line managers while making HR related decisions and provides further impetus to our first research hypothesis.

Table 5: Change of line management responsibility on HR issues over the last three years (\%)

\begin{tabular}{|l|r|r|r|}
\hline Main sector of business & Increased & Same & Decreased \\
\hline Pay and Benefits & 50 & 45 & 5 \\
\hline Recruitment and Selection & 51 & 45 & 4 \\
\hline Training and Development & 45 & 48 & 7 \\
\hline Performance Appraisal & 50 & 43 & 7 \\
\hline Labor Relation & 26 & 68 & 6 \\
\hline Health and Safety & 35 & 60 & 5 \\
\hline Workforce Expansion / Reduction & 45 & 51 & 4 \\
\hline
\end{tabular}

\section{Devolvement and Impact on Organizational Performance}

In this study, more or less devolved organizations are differentiated by asking to the respondents about the primary responsibility lying for major policy decisions on pay and benefits, recruitment and selection, training and development, labor relation, health and safety, and workforce expansion/reduction. The second hypothesis was about impact of high or low devolvement on organizational performance. Respondents were asked about the change of line management responsibility over three years on abovementioned issues. Every respondent in organizations has marked their position in between seven to twenty-eight on these seven HR management practices. The organizations, which have the practice of partnership, consultation in between line management and HR department, are recognized as more devolved organizations. According to this cutoff line, those organizations, which have at least twenty one score on these issues and have either increased or remained same of the line management responsibility in all these issues over the three years are considered as more devolved organizations. Altogether forty-two percent organizations fall into the category of more devolved organizations.

Partnership approach to some extent introduced on major policy areas of HR management in business sectors, it is not sufficient because majority of organizations focused on traditional HR function of line management domination ignoring HR department expertise. From the above table (Table 6) it is clear that the involvement of line managers is high in different HR responsibility. According to the respondents, organizations categorized as more-assigned are involving line managers in different types of HR responsibilities. The discriminant analysis of table 6 shows the two categories of organizations are practicing their HR practices differently which are statistically significant to be claimed. Overall forty four Nepalese listed companies are grouped in high assigned organizations indicates the partnership approach between line management and HR department while 
managing people in an organizations. The majorities of organizations (that is, 57.5 percent) HR practices is still somehow dominated by line management practices and have less partnership approach while managing human capital.

Table 6: Discriminant Analysis for devolvement

\begin{tabular}{|c|c|c|c|c|c|c|}
\hline \multirow{2}{*}{$\begin{array}{l}\mathbf{S . N .} \\
1\end{array}$} & \multirow{2}{*}{$\begin{array}{l}\text { Primary responsibility } \\
\text { and decision lie to line } \\
\text { management on: } \\
\text { Pay and Benefits }\end{array}$} & \multicolumn{2}{|c|}{$\begin{array}{l}\text { Group 1: High- } \\
\text { Assigned } \\
\text { Organization } \\
(\mathrm{N}=44)\end{array}$} & \multicolumn{2}{|c|}{$\begin{array}{l}\text { Group 2: Low- } \\
\text { Assigned } \\
\text { Organization } \\
(\mathrm{N}=61)\end{array}$} & \multirow{2}{*}{$\begin{array}{l}\text { F-test } \\
20.80^{* *}\end{array}$} \\
\hline & & 3.18 & 0.81 & 2.21 & 1.23 & \\
\hline 2 & $\begin{array}{l}\text { Recruitment and } \\
\text { Selection }\end{array}$ & 3.18 & 0.89 & 2.28 & 1.18 & $18.07 * *$ \\
\hline 3 & $\begin{array}{l}\text { Training and } \\
\text { Development }\end{array}$ & 3.25 & 0.81 & 2.38 & 1.19 & $17.51 * *$ \\
\hline 4 & Labor Relations & 3.25 & 0.81 & 2.24 & 1.25 & $21.83 * *$ \\
\hline 5 & Health and Safety & 3.20 & 0.70 & 2.13 & 1.15 & $30.30 * *$ \\
\hline 6 & Performance Appraisal & 3.20 & 1.09 & 2.13 & 1.15 & $27.05^{* *}$ \\
\hline 7 & $\begin{array}{l}\text { Workforce } \\
\text { Expansion/Reduction }\end{array}$ & 3.38 & 1.02 & 2.18 & 1.20 & $17.66 * *$ \\
\hline
\end{tabular}

Note: $* * p<0.01 ;$ Chi-square $=54.345 ;$ Significance $=0.000$

\section{Assignment of HR management responsibility and overall organizational performance}

Discussion above show that even though some Nepalese organizations initiated sharing of HR management responsibility in between line management and HR department, in majority of the organizations line management are responsible to implement HR practices.

Table (7) shows that high devolved organizations have achieved superior organizational performance in terms of quality of product, labor productivity, financial performance, employee satisfaction, rate of innovation, employee commitment, and market share than the less devolved organizations. The findings proved our second hypothesis that firms, which have high assignment of HR management practices to the line management, are better in organizational performance compared to low assigned firms. 
Table 7: Assignment of HR management responsibility and firm performance

\begin{tabular}{|c|c|c|c|c|c|c|c|c|}
\hline \multirow{3}{*}{$\begin{array}{l}\text { Perceptual } \\
\text { organizational } \\
\text { Performance in terms } \\
\text { of }\end{array}$} & \multicolumn{6}{|c|}{$\begin{array}{c}\text { Nature of Organizations } \\
\end{array}$} & \multirow{3}{*}{$\begin{array}{l}\text { t- } \\
\text { value* }\end{array}$} & \multirow{3}{*}{$\begin{array}{l}\text { P- } \\
\text { value }\end{array}$} \\
\hline & \multicolumn{3}{|c|}{$\begin{array}{l}\text { Low Assigned } \\
\text { Organization }(\mathrm{N}=61)\end{array}$} & \multicolumn{3}{|c|}{$\begin{array}{l}\text { High Assigned } \\
\text { Organization }(\mathrm{N}=44)\end{array}$} & & \\
\hline & mean & S.D. & SEM & mean & S.D. & SEM & & \\
\hline Quality of product & 3.38 & 0.66 & 0.08 & 4.06 & 0.62 & 0.09 & -5.45 & .00 \\
\hline Level of labor productivity & 3.41 & 0.71 & 0.09 & 3.88 & 0.69 & 0.10 & -3.43 & .00 \\
\hline Financial performance & 3.47 & 0.69 & 0.08 & 3.93 & 0.73 & 0.11 & -3.22 & .00 \\
\hline Employee satisfaction & 3.38 & 0.71 & 0.09 & 3.70 & 0.73 & 0.11 & -2.28 & .02 \\
\hline Rate of innovation & 3.13 & 0.78 & 0.10 & 3.59 & 0.72 & 0.11 & -3.09 & .00 \\
\hline Employee commitment & 3.28 & 0.55 & 0.07 & 4.04 & 0.57 & 0.08 & -6.90 & .00 \\
\hline Market share & 3.29 & 0.82 & 0.10 & 3.72 & 0.82 & 0.12 & -2.66 & .01 \\
\hline
\end{tabular}

*Equal variance not assumed; SEM = Standard Error Mean

\section{CONCLUSION}

This research clearly highlighted that there is a higher level of sole responsibility enjoyed by the line management for decisions over workforce expansion/reduction, pay and benefits, labor relations, health and safety, and recruitment and selection. Much higher than international practice, in majority of organizations of Nepal, line management actively involved either alone or in consultation with HR department while making most of HR management decisions. The decision-making responsibility of HR management department alone is comparatively less: seven percent in pay and benefits and workforce expansion/reduction and almost ten to twelve percent in rest of all issues of HR management. Though line management is in dominating position, the partnership in between line management and HR management department also exists while making HR management decisions.

Line managers' role in different HR management practices is dominating. This might be the reason that line managers in these organizations are more familiar with HR practices, and HR departments are weak alone to initiate HR practices. Some other reasons might be that professionally $H R$ department needs to develop its HR management skills or HR staffs in the department are not motivated due to lower influence in making business strategy. In case of Nepalese organizations, line managers have time for HR initiatives and it is accepted in practice. As viewed by Guest (1989) line managers accepted and use HR management practices as part of their everyday work. There is the advantage of accepting HR responsibility by the line managers. For example, as described by Whittaker and Marchington (2003) involvement of line managers can help to fit business strategy development and HR development, which is primary gateway for achieving competitive advantage.

As stated by many authors including Brewster and Larsen (2000), Ulrich (1998) Budhwar and Sparrow (1997) that the rational for the assignment of HR management responsibility is that it has positive impact on organizational performance. It helps reduce costs, improves commitment, motivates in 
maintaining good industrial relation and supports to increase productivity. The result clearly provides evidence that high assignment organizations of Nepal are doing better firm performance than low assignment organizations. The most significant result of this study is that it is found that high assignment organizations are successfully increasing labor productivity, financial performance, rate of innovation, employee satisfaction and commitment, and extending market share. The analysis of secondary data also supports this finding. This study supports international practices that high-devolved organizations outperform than the less devolved organizations. These findings certainly contribute to decision makers involved in people management practices about the significance of partnership between HR experts and line management and its impact on overall organizational performance.

\section{REFERENCES}

Adhikari, D. R. (1999). Human Resource management in Nepal: Policies and Practices. Leopold-Franzens-University, Innsbruck, Austria.

Adhikari, D. R. (2000). Development in the management of Human Resources in Nepal. Leopold-Franzens-University, Innsbruck, Austria.

Adhikari, D. R. and Gautam, D. K. (2007). Empowering Nepalese Managers for Organizational Performance. Paper presented in the Twelve International Conference of Asia Pacific Researchers in Organizational Studies (APROS12) at management Development Institute, December 9-12, India.

Adhikari, D. R. and Gautam, D. K. (2008). Labour Legislations for Improving Quality of Work Life in Nepal. Paper Presented in the Indian Society for Labour Economics (ISLE), Giri Institute of Development Studies, Lucknow, India December, 13-15.

Adhikari, D. R. and Gautam, D. K. (2009). Integration of Business-Human Resource strategy for Organizational Performance (Forth coming).

Adhikari, D. R. and Mueller, M. (2004). Human Resource management in Nepal. In Budhwar, P. and Debra, Y. (Eds.) Human Resource management in Developing Countries, Routledge, London, 91-101.

Atterbury, S.; Brewster, C.; Communal, C.; Cross, C.; Gunnigle, P. and Morley, M. (2004). The UK. and Ireland: Traditions and Transitions in HR management. In C. Brewster; W. Mayrhofer and M. Morley (eds.), HR management in Europe: Evidence of Convergence? Elsevier ButterworthHeinemann, Burlington.

Barney, J. and Wright, P. M. (1998). On Becoming a Strategic Partner: The Role of Human Resources in Gaining Competitive Advantage. Human Resource management, 37, 1, 31-46.

Brewster, C. and Larsen, H. H. (1992). Human Resource management in Europe: Evidence from Ten Countries. International Journal of Human Resource management, 3, 3 409-434.

Brewster, C. and Larsen, H. H. (eds.) (2000). Human Resource management in Northern Europe: Trends, Dilemmas and Strategy. Blackwell, Oxford.

Brewster, C. and Soderstrom, M. (1994). Human Resources and Line management. In C. Brewster and A. Hegewisch (eds.), Policy and Practices in European Human Resource management: The Price Waterhouse Cranfield Survey. Routledge, London, 51-67. 
Brewster, C.; Larsen, H. H. and Mayrhofer, W. (1997). Integration and Assignment: A Paradox in Human Resource management. Journal of International management, 3, 1, 1-23.

Budhwar, P. (2000). Evaluating Levels of Strategic Integration and Devolvement of Human Resource management in the UK. Personnel Review, 29, 2, 141161.

Budhwar, P. and Sparrow, P. (1997). Evaluating Levels of Strategic Integration and Devolvement of Human Resource management in India. International Journal of Human Resource management, 8, 4, 476-494.

Burke, R. J. and Cooper, C. L. (2005). The Human Resource Revolution: Why Putting People First Matters. In R. J. Burke and C. L. Cooper (eds.), Reinventing Human Resource management: Challenges and New Directions. Routledge.

Buyens, D.; Dany, F.; Dewettinck, K. and Quinodon, B. (2004). France and Belgium: Language, Culture and Differences in HR Practices. In C. Brewster, W. Mayrhofer and M. Morley (eds.), HR management in Europe: Evidence Of Convergence? Elsevier Butterworth-Heinemann, Burlington.

Cooper, C. (2001). Win By a Canvas. People management, 25 January.

CRANET, (2005). CRANET Survey on Comparative Human Resource management. International Executive Report 2005, CRANET, UK, available at http://www.cranet.org.

Cully, M.; Woodland, S.; O'reilly, A. and Dix, G. (1999). Britain at Work: As Depicted by the 1998 Workplace Employee Relations Survey. Routledge, London.

Cunningham, I. and Hyman, J. (1995). Transforming the Human Resource management Vision into Reality: The Role of Line Managers and Supervisors in Implementing Change. Employee Relations, 17, 8, 5-21.

Cunningham, I. and Hyman, J. (1999). Devolving Human Resource Responsibilities to the Line. Personnel Review, 28, 1/2, 9-27.

Cunningham, I.; Hyman, J. and Baldry, C. (1996). Empowerment: The Power to Do What? Industrial Relations Journal, 27, 2, 143-154.

Cunningham, J. and Debrah, Y. A. (1995). Skills for Managing Human Resources in a Complex Environment: The Perceptions of Human Resource management in Singapore. International Journal of Human Resource management., 6, 1, 79-101.

Currie, G. and Procter, S. (2001). Exploring the Relationship Between Human Resource and Middle Managers. Human Resource management Journal, 11, 1, 53-69.

Earnshaw, J.; Marginton, M. and Goodman, J. (2000). Unfair to Whom? Discipline and Dismissal in Small Establishments. Industrial Relation Journal, 31, 1, 62-73.

Erten, C.; Strunk, G.; Gonzalez, J. and Hilb, M. (2004). Austria and Switzerland: Small Countries with Large Differences. In C. Brewster, W. Mayrhofer and M. Morley (eds.) HR management in Europe: Evidence of Convergence? Elsevier Butterworth- Heinemann, Burlington.

Gautam, D. K. and Davis, A. J. (2007). Integration and Devolvement of Human Resource Practices in Nepal. Employee Relations, 29, 6, 711-726. 
Gennard, J. and Kelly, J. (1997). The Unimportance of Labels: The Diffusion of the Personnel/ HR management Function. Industrial Relation Journal, 28, 1, 2742.

Gratton, L.; Hope-Hailey, V.; Stiles, P. and Truss, P. (1999). Strategic Human Resource management. Oxford University Press.

Guest, D. (1989). Personnel and Human Resource management: can you tell the Difference? Personnel management, 21, 1, 48-51.

Guest, D. and King, Z. (2001). Human Resource and the Bottom Line. People management, 27, 24-29.

Hall, L. and Torrington, D. (1998). Letting go or Holding on - The Devolution of Operational Personnel Activities. Human Resource management Journal, 8, $1,41-55$.

Hedlung (1986) see in The Hypermodern MNC- A Heterarchy? Human Resource management, 25,pp. 9-35.

Hope-Hailey, V.; Gratton, L.; McGovern, P.; Stiles, P.; and Truss, C. (1997). A Chameleon Function? HR management in '90s. Human Resource management Journal, 7, 5-18.

Huang, T. (2000). Are the Human Resource Practices of Effective Firms Distinctly Different from that type of Poorly Performing Ones? Evidence from Taiwanese Enterprise. International Journal of Human Resource management, 2, 11, 436-51.

Hutchinson, S. (1995). Variations in the Partnership Model. People management, $22,1,38-55$

Hutchinson, S. and Wood, S. (1995). Personnel and the Line: Devolving a New Relationship. Institute of Personnel and Development, London, 3-42.

IRS (Industrial Relations Service) (2000). Holding the Line. Employment Trend, No. 707, 5-9.

IRS (Industrial Relations Services) (1994). The Center Cannot Hold: Devolving Personnel Duties. Employment Trend, 566, August. 6-12.

IRS (Industrial Relations Services) (1995). Changes in Personnel. Employment Trends, 598, December, 5-9.

IRS (Industrial Relations Services) (1996). The Changing World of Personnel. Employment Trend, 604, March 5-11.

Jackson, S. E. and Schuler, R. S. (2000). Managing Human Resources: a Partnership Perspective. International Thomson Publishing, London.

Kirkpatrick, I.; Davies, A. and Oliver, N. (1992). Decentralization: Friend or Foe of Human Resource management? In P. Blyton and P. Turnbull (eds.) Reassessing Human Resource management. Sage, London, 131-148.

Koubek, J. and Vatchkova, E. (2004). Bulgaria and Czech Republic: Countries in Transition. In C. Brewster, W. Mayrhofer and M. Morley (eds.) HR management in Europe: Evidence of Convergence? Elsevier ButterworthHeinemann. Burlington.

Larsen, H. H. and Brewster, C. (2003). Line management Responsibility for HR management: What's happening in Europe? Employee Relations, 25, 3, 228-244.

Legge, K. (1989). Human Resource management: A Critical Analysis. In J. Storey (ed.) New Perspective on Human Resource management. London. Routledge 19-55. 
Legge, K. (1995). Human Resource management: Rhetoric and Realities. Macmillan, London.

Lindeberg, T.; Manson, B. and Vanhala, S. (2004). Sweden and Finland: Small Countries with Large Companies. In C. Brewster, W. Mayrhofer and M. Morley (eds.) HR management in Europe: Evidence of Convergence? Elsevier Butterworth- Heinemann, Burlington.

Lowe, J. (1992). Locating the Line: The Front Line Supervisor and Human Resource management. In P. Blyton and P. Turnbell (eds.) Reassessing Human Resource management. Sage, London, 148-68

Marchington, M. (1999). Professional Qualification Scheme: Core Personnel and Development Exam Papers and Examiners. Paper given to IPD Professional Standard Conference, University of Warwick, July, IPD, 1-12.

McGovern, P.; Gratton, L.; Hope-Hailey, V.; Stiles, P. and Truss, C. (1997). Human Resource management on the Line. Human Resource management Journal, 7, 4, 12-29.

Millward, N.; Steven, M.; Smart. D. and Hawes, W. R. (1992). Workplace Industrial Relations in Transition. Dartmouth, Aldershot.

Mohrman, S. A. and Lawler, E. E. (1999). The New Human Resource management: Creating the Strategic Business Partnership. In R. S. Schuler and S. E. Jackson. (eds.) Strategic Human Resource management. Blackwell, Oxford.

NEPSE (2007). Listed companies of Nepal. Available at http://www.nepalstock.com/listedcomp.html accessed on March 5, 2007.

Othman, R. B. (1996). Strategic Human Resource management: Evidence from the Irish Food Industry. Personnel Review, 25, 1, 40-58.

Papalexandris, N. and Stavrou-Costea, E. (2004). Italy, Greece and Cyprus: HR management in the South -Eastern Mediterranean Corner of the EU. In C. Brewster; W. Mayrhofer and M. Morley (eds.) HR management in Europe: Evidence of Convergence? Elsevier Butterworth- Heinemann. Burlington.

Pool, M. (1976). A Power Analysis of Work Place Labor Relations. Industrial Relation Journal, 7, 3, 31-43.

Pool, M. and Jenkins, G. (1997). Responsibility for HR management Practices in the Modern Enterprise: Evidence from Britain. Personnel Review, 26, 5, 333356.

Renwick, D. (2000). HR-Line Work Relations: A Review, Pilot Case and Research Agenda. Employee Relations, 22, 2, 179-205.

Renwick, D. (2003). Line Manager Involvement in Human Resource management: An Inside View. Employee Relations, 25, 3, 262-280.

Rogaczewska, A. P.; Larsen. H. H.; Nordhaug, E. D. and Gjelsvik, M. (2004). Denmark and Norway: Siblings or Cousing? In C. Brewster, W. Mayrhofer and M. Morley (eds.) HR management in Europe: Evidence of Convergence? Elsevier Butterworth- Heinemann, Burlington.

Schuler, R. (1990). Repositioning the Human Resource Function: Transformation or Demise? Academy of management Executive, 4, 3, 49-60.

Schuler, R. (1991). Linking the People with the Strategic Needs of the Business. Organizational Dynamics, Summer, 18-32.

Schuler, R. (1992). Strategic Human Resource management: Linking the People with the Needs of the Business. Organizational Dynamics, 4, 18-32. 
Schuler, R. and Walker, J. (1990). Human Resource Strategy: Focusing on Issues and Actions. Organizational Dynamics, Summer, 5-19.

Storey, J. (1992). Developments in the management of Human Resources. Oxford: Blackwell, London.

Storey, J. (2001). Human Resource management Today: An Assessment in J. Storey (ed.), Human Resource management: A Critical Text. Thomson, London.

Storey, J. and Sisson, K. (1994). Managing Human Resources and Industrial Relations. Buckingam: Open University Press.

Torrington, D. (1989). Human Resource management and the Personnel Function. In J. Storey (ed.), New Perspectives on Human Resource management. London: Routledge.

Ulrich, D. (1997). Human Resource Champions, the Next Agenda for Adding Value and Delivering Results. Boston. Massachusetts: Harvard Business School Press.

Ulrich, D. (1998). A New Mandate for Human Resource. Harvard Business Review, 124-134.

Ulrich, D. (2001). The Evaluation of a Professional Agenda. Mastering People management, 15, 2-3.

Whittaker, S. and Marchington, M. (2003). Devolving Human Resource Responsibility to the Line. Employee Relations, 25, 3, 245-261. 